\title{
Study of Hepatitis B Virus Genotypes and Mutation in 1762 \& 1764 Nucleotides of X Gene in Chronic HBV Patients from Golestan Province-Iran
}

\author{
Sareh Zhand ${ }^{1}$, Ghassem Rostamian², Alijan Tabarraei1 ${ }^{1}$, Abdolvahab Moradi ${ }^{*}$ \\ ${ }^{1}$ Department of Microbiology, School of Medicine, Golestan University of Medical Sciences, Gorgan, Iran \\ ${ }^{2}$ Department of Medicine, School of Medicine, Iran University of Medical Sciences, Tehran, Iran \\ Email: Sa_zh2006@yahoo.com, ghassem.rostamian@yahoo.com, Alijant@yahoo.com, *abmoradi@yahoo.com
}

How to cite this paper: Zhand, S., Rostamian, G., Tabarraei, A. and Moradi, A. (2016) Study of Hepatitis B Virus Genotypes and Mutation in $1762 \& 1764$ Nucleotides of $\mathrm{X}$ Gene in Chronic HBV Patients from Golestan Province-Iran. Health, 8, 1397-1401. http://dx.doi.org/10.4236/health.2016.813140

Received: November 29, 2015

Accepted: October 18, 2016

Published: October 21, 2016

Copyright $\odot 2016$ by authors and Scientific Research Publishing Inc. This work is licensed under the Creative Commons Attribution International License (CC BY 4.0).

http://creativecommons.org/licenses/by/4.0/ (c) (i) Open Access

\section{Abstract}

Introduction: More than 350 million people are chronic carriers of HBV and many of them develop progressive diseases, including cirrhosis and hepatocellular carcinoma. Many of those infected develop persistent disease and a proportion goes on to develop liver failure and cancer. Researchers showed that double mutations of the $\mathrm{x}$ gene at position 1762 and 1764, have been found in chronic hepatitis B. These mutations were proposed to be associated with fulminant hepatitis B increasing risk of hepatocellular carcinoma. This project aimed to investigate mutation in the $\mathrm{x}$ gene region of HBV infected patients in Golestan province, Iran. Method: 100 patients were entered in this study. Hepatitis B viral DNA was extracted from plasma and PCR was performed using specific primers. Direct sequencing and alignment of $\mathrm{x}$ gene were applied using reference sequence from Gene Bank database (Okamoto, 1988; Accession number AB033559). Results: Among the chronic HBV patients 51\% were male. The results showed that $49 \%$ of patients had A1762T, G1764A mutations changing AGG to stop codon TGA. $27 \%$ and $24 \%$ of cases were showed mutation only in A1762T and G1764A positions respectively. Conclusion: This study was shown presence of $\mathrm{X}$ gene mutation in HBV infected people in Golestan province, Iran. The rate of mutation in two positions 1762 and 1764 of HBV genotype D X gene was higher than the average rate of the world (34\%).

\section{Keywords}

HBV, X Gene, Mutation, Genotype, Iran

\section{Introduction}

Hepatitis B Virus (HBV) infection is a global health problem, and more than 350 mil- 
lion people in the world are chronic carriers of the virus [1]. The clinical manifestations of HBV infection range from acute self-limiting infection or fulminant hepatic failure, inactive carrier state, chronic hepatitis with progression to cirrhosis, and Hepatocellular Carcinoma (HCC) [2]. Genotype D in the Mediterranean area, Middle East and Iran differ with regard to clinical outcome, prognosis, and response treatment [3]. HBV is a small, DNA-containing virus with 4 overlapping open reading frames (i.e., several genes overlap and use the same DNA to encode viral proteins. The 4 open reading frame (ORF) are core, surface, $\mathrm{X}$, and polymerase. The core gene encodes the core nucleocapsid protein (important in viral packaging) and hepatitis B e antigen ( $\mathrm{HBeAg}$ ). The surface gene encodespre- $S_{1}$, pre- $S_{2}$, and $S$ protein (yielding large, middle, and small surface proteins, respectively). The $\mathrm{X}$ gene encodes the $\mathrm{X}$ protein, which has transactivating properties and may be important in hepatic carcinogenesis. The polymerase gene encodes a large protein with functions critical for packaging and DNA replication (including priming, RNA and DNA dependent DNA polymerase, and RnaseH activities) [4]. The $\mathrm{X}$ gene is the smallest of the four, partially overlapping open reading frames (ORFs) of the Hepatitis B Virus (HBV) genome. It codes for a 154-amino-acid polypeptide designated $\mathrm{HBxAg}$ or $\mathrm{X}$ protein. The main function of the $\mathrm{X}$ protein is as a transcriptional activator and it has been shown to transactivate a number of cellular and viral promoters [5]. The basic core promoter (BCP; at nucleotide [nt] region 1742 1849), the core upstream regulatory sequences (CURS; atnt region 1643 - 1742), and the negative regulatory element (NRE; at nt region 1611 - 1634) are located mainly in the HBVX gene and play an important role in replication and hepatitis B core antigen/ HBeAg formation. Formation of the 3.5-kbpregenome messenger RNA (mRNA), which serves for translation, of the core and polymerase proteins, and the precore/core mRNA for translation of $\mathrm{HBeAg}$, is controlled by the BCP and CURS. Within these regions various mutations have been described affecting the precore start codon, the encapsidation signal, and the core promoter region. The most common of these nucleotide exchanges is a G1764A mutation, which is often associated with an A1762T mutation. The G1764A mutation is located within the BCP, upstream of the pregenome and precore/core mRNA initiation sites and may thus be involved in transcriptional regulation [6]. The most common naturally occurring HBV mutations are the G1896A mutations, which create a premature stop codon in the precore (PC) region, and the A1762T, G1764A dual mutation in the core promoter (CP) region, which down-regulates $\mathrm{HBeAg}$ production [7]. Iran is considered as a country with low endemicity of chronic HBV infection [8], however, comparing to higher prevalence of HBV infection in Golestan Province with about $8.9 \%$ in comparison with other studies published in Iran to date (3\%) [9]. This study aimed to investigate the rate of mutation in the $\mathrm{X}$ gene region of $\mathrm{HBV}$ in patients infected by this virus in Golestan Province, Iran.

\section{Materials and Methods}

\subsection{Sample Selection}

According to lowest frequency of the HBV PC mutation $(p=48 \%)$ and error coefficient 
$(\mathrm{d}=0.096)$ and confidence $95 \%=1.96,100$ patients with proved chronic HBV infection for more than two years according to clinical and paraclinical evidence from Golestan Province Iran, during year 2008 to 2012 participated in this study. The research project has received the confirmation of the Ethics Committee. None of the patients were vaccinated for HBV or had any antiviral therapy; all patients had negative results for antibodies against hepatitis C, hepatitis D and Human Immunodeficiency Virus. Blood samples were collected in the EDTA 5\% anti-coagulant and plasma was separated for further examination.

\subsection{DNA Extraction}

HBV-DNA was extracted from $200 \mu \mathrm{l}$ of each plasma sample using QIAamp DNA Mini Kit (QIAGEN, Hamburg, Germany) following the manufacturer's instruction and extracted DNA was stored at $-20^{\circ} \mathrm{C}$ for PCR process.

\subsection{Primer Selection}

Primers were selected to achieve optimum PCR sensitivity and the PreCore region amplification. Following primers yielded $390 \mathrm{bp}$ amplification according to nucleotide position 1689 to 2078 [7].

5'ACCTTGAGGCATACTTCAAA3'(Forward)-1689-1708

5'CAGAATAGCTTGCCTGAGTGC3'(Reverse)-2058-2078

\subsection{PCR and DNA Amplification}

Amplification mixture contained: $100 \mathrm{ng}$ of extracted DNA, $1 \times$ PCR buffer, $1.5 \mathrm{mM}$ $\mathrm{MgCl}_{2}, 0.2 \mathrm{mM} \mathrm{dNTP}, 2.5 \mathrm{U}$ Taq DNA polymerase (QIAGEN, Hamburg, Germany) and $0.4 \mathrm{pmol} / \mu \mathrm{l}$ of each primer in a total volume of $50 \mu \mathrm{l}$ with distilled water. The PCR profile was an initial $5 \mathrm{~min}$ denaturation at $95^{\circ} \mathrm{C}$, followed by 30 cycles of amplification including denaturation for $1 \mathrm{~min}$ at $95^{\circ} \mathrm{C}$, primer annealing for $1 \mathrm{~min}$ at $55^{\circ} \mathrm{C}$ and extension for $2 \mathrm{~min}$ at $72^{\circ} \mathrm{C}$, with a final extension at $72^{\circ} \mathrm{C}$ for $5 \mathrm{~min}$. The $390 \mathrm{bp}$ amplification products were analyzed by gel electrophoresis on $1 \%$ agarose gel stained with ethidium bromide to determine HBV-DNA positive and negative samples.

\subsection{DNA Sequencing and Mutation Analysis}

The positive PCR products were send to Macrogen Inc., Korea for automated sequencing Then nucleotide sequences were aligned with standard hepatitis B sequence, [Accession number: AB033559] from Gene Bank database, for mutation detection and analysis [8].

\section{Results}

The mean age of patients was $36.8 \pm 11.5$ year and $51 \%$ was male. Isolates were belonged to genotype $\mathrm{D}$ subgenotype $\mathrm{D}_{1}$, subtype ayw $\mathrm{w}_{2}$ according to our previous study [9]. Comparison of our nucleotide sequences with reference sequence from Gene Bank database (Okamoto, 1988; Accession number AB033559) showed high rate of mutation 
with frequency of $97.5 \%$ in BCP region. Substitutions of A1762T and A1762G were detected in $25(25 \%)$ and $5(5 \%)$ of patients respectively which were affected amino acid L130M in 10 (10\%) patients. G1764A, G1764T and G1764C substitution were seen in $24(24 \%), 16(16 \%)$ and 4 (4\%) cases respectively which caused V131I change in 9 (9\%) patients. $27 \%$ and $25 \%$ of cases were showed mutation only in A1762T and G1764A positions respectively. $49 \%$ of patients had A1762T, G1764A mutations changing AGG to stop codon TGA.

\section{Discussion}

HBV mutants which have various mutations in the $\mathrm{X}$ gene, including deletions or insertions of nucleotides and point Mutations have been reported [10]. These mutations are clustered within the region from positions 1750 to 1770 of the HBV genome, with an A-to-T mutation at 1762 and a G-to-A mutation at 1764 being the most common [11]. The pattern emerging for nucleotide identity at positions 1762 and 1764 strongly suggests a correlation with $\mathrm{HBeA}$ ganti-HBe phenotypic expression [5]. In vitro experiments by Buckwold et al. (1996) have indicated that precore mRNA production and consequently $\mathrm{HBeAg}$ levels are reduced when positions 1762 to 1764 are mutated to TGA, probably as a result of reduced transcription factor binding [4]. In summary, the BCP T1762/A1764 mutation is the strongest viral factor associated with the development of HCC in hepatitis B carriers. Patients infected with the BCP T1762/A1764 mutant who had an HBV load_105 copies/mL had a _30-fold increase in the risk of developing HCC, compared with patients infected with the BCP A1762/G1764 wild-type strain and a low HBV load, irrespective of viral genotype and precore 1896 status. This high relative risk indicates that both the BCP T1762/A1764 mutation and HBV load are important in better defining HBV carriers at high risk for progression to HCC [12]. Lee et al., showed that double mutations of HBV at nucleotide1762 $(\mathrm{A} \rightarrow \mathrm{T})$ and $1764(\mathrm{G} \rightarrow$ $\mathrm{A})$ in the basal core promoter $(\mathrm{BCP})$ region were the most common mutation types in HCC patients. Because double mutations in the BCP region also exist in the coding sequence of HBV X gene, these mutations convert $\mathrm{K}$ to $\mathrm{M}$ at position 130 and $\mathrm{V}$ to $\mathrm{I}$ at position 131 in the overlapping X-open reading frame gene product [13]. Detection of the BCP T1762/A1764 mutation in HBV carriers may aid in the identification of chronic carriers at high risk for developing HCC, and they may be encouraged more aggressively to receive antiviral treatment and to undergo more active surveillance for HCC [12].

\section{Conclusion}

This study was shown presence of X gene mutation in HBV infected people in Golestan province, Iran. The rate of mutation in two positions 1762 and 1764 of HBV genotype D X gene $24 \%$ and $27 \%$ was near the average rate of the world (40\%) [14].

\section{References}

[1] Ataollahi, M.R., Daneshian, M., Paknahad, M.R., Paknahad, S., Pouraskar, M. and Pakna- 
had, A. (2016) Hepatitis B and Its Related Factors: A Review.

[2] Kao, J.H., Chen, P.J., Lai, M.Y. and Chen, D.S. (2003) Basal Core Promoter Mutations of Hepatitis B Virus Increase the Risk of Hepatocellular Carcinoma in Hepatitis B Carriers. Gastroenterology, 124, 327-334. http://dx.doi.org/10.1053/gast.2003.50053

[3] Liu, S., Zhang, H., Gu, C., Yin, J., He, Y., Xie, J., et al. (2009) Associations between Hepatitis B Virus Mutations and the Risk of Hepatocellular Carcinoma: A Meta-Analysis. Journal of the National Cancer Institute, 101, 1066-1082. http://dx.doi.org/10.1093/jnci/djp180

[4] Hunt, C.M., McGill, J.M., Allen, M.I. and Condreay, L.D. (2000) Clinical Relevance of Hepatitis B Viral Mutations. Hepatology, 31, 1037-1044.

http://dx.doi.org/10.1053/he.2000.6709

[5] Kidd-Ljunggren, K., Oberg, M. and Kidd, A. (1997) Hepatitis B Virus X Gene 1751 to 1764 Mutations: Implications for HBeAg Status and Disease. Journal of General Virology, 78, 1469-1478. http://dx.doi.org/10.1099/0022-1317-78-6-1469

[6] Erhardt, A., Reineke, U., Blondin, D., Gerlich, W.H., Adams, O., Heintges, T., et al. (2000) Mutations of the Core Promoter and Response to Interferon Treatment in Chronic Replicative Hepatitis B. Hepatology, 31, 716-725. http://dx.doi.org/10.1002/hep.510310323

[7] Hussain, M., Chu, C.-J., Sablon, E. and Lok, A.S. (2003) Rapid and Sensitive Assays for Determination of Hepatitis B Virus (HBV) Genotypes and Detection of HBV Precore and Core Promoter Variants. Journal of Clinical Microbiology, 41, 3699-3705.

http://dx.doi.org/10.1128/JCM.41.8.3699-3705.2003

[8] Alavian, S.M., Fallahian, F. and Lankarani, K.B. (2007) The Changing Epidemiology of Viral Hepatitis B in Iran. Journal of Gastrointestinal and Liver Diseases, 16, 403.

[9] Gholamreza, R., Shahryar, S., Abbasali, K., Hamidreza, J., Abdolvahab, M., Khodaberdi, K., et al. (2007) Seroprevalence of Hepatitis B Virus and Its Co-Infection with Hepatitis D Virus and Hepatitis C Virus in Iranian Adult Population. Indian Journal of Medical Sciences, 61, 263. http://dx.doi.org/10.4103/0019-5359.32092

[10] Okamoto, H., Tsuda, F., Akahane, Y., Sugai, Y., Yoshiba, M., Moriyama, K., et al. (1994) Hepatitis B Virus with Mutations in the Core Promoter for an e Antigen-Negative Phenotype in Carriers with Antibody to e Antigen. Journal of Virology, 68, 8102-8110.

[11] Parekh, S., Zoulim, F., Ahn, S.H., Tsai, A., Li, J., Kawai, S., et al. (2003) Genome Replication, Virion Secretion, and e Antigen Expression of Naturally Occurring Hepatitis B Virus Core Promoter Mutants. Journal of Virology, 77, 6601-6612. http://dx.doi.org/10.1128/JVI.77.12.6601-6612.2003

[12] Liu, C.-J., Chen, B.-F., Chen, P.-J., Lai, M.-Y., Huang, W.-L., Kao, J.-H., et al. (2006) Role of Hepatitis B Viral Load and Basal Core Promoter Mutation in Hepatocellular Carcinoma in Hepatitis B Carriers. Journal of Infectious Diseases, 193, 1258-1265. http://dx.doi.org/10.1086/502978

[13] Lee, J.-H., Han, K.-H., Lee, J.M., Park, J.H. and Kim, H.-S. (2013) Impact of Hepatitis B Virus (HBV) X Gene Mutations on Hepatocellular Carcinoma Development in Chronic HBV Infection. Clinical and Vaccine Immunology, 20, 127. http://dx.doi.org/10.1128/CVI.00661-12

[14] Yan, T., Li, K., Su, H., Liu, X., Zang, H. and Wang, H. (2010) Analysis the Relationship of HBV BCP A1762T/G1764A Double Mutation with HBV Related Acute on Chronic Liver Failure. Chinese Journal of Experimental and Clinical Virology, 24, 190-192. 
Submit or recommend next manuscript to SCIRP and we will provide best service for you:

Accepting pre-submission inquiries through Email, Facebook, LinkedIn, Twitter, etc. A wide selection of journals (inclusive of 9 subjects, more than 200 journals)

Providing 24-hour high-quality service

User-friendly online submission system

Fair and swift peer-review system

Efficient typesetting and proofreading procedure

Display of the result of downloads and visits, as well as the number of cited articles

Maximum dissemination of your research work

Submit your manuscript at: http://papersubmission.scirp.org/

Or contact health@scirp.org 